\title{
Centrodinium punctatum (Dinophyceae) produces significant levels of saxitoxin and related analogs
}

\author{
Shin Hyeon Ho 1, ${ }^{\text {, Li Zhun }}{ }^{2}$, Réveillon Damien ${ }^{3}$, Rovillon Georges-Augustin ${ }^{3}$, Mertens Kenneth 4 , \\ Hess Philipp ${ }^{3}$, Kim Hyun Jung ${ }^{1}$, Lee Jihoon ${ }^{5}$, Lee Kyun-Woo ${ }^{5}$, Kim Daekyung ${ }^{6}$, Park Bum Soo ${ }^{7}$, \\ Hwang Jinik ${ }^{8}$, Seo Min $\mathrm{Ho}^{9}{ }^{9}$, Lim Weol Ae ${ }^{10}$
}

${ }^{1}$ Library of Marine Samples, Korea Institute of Ocean Science \& Technology, Geoje 656-830, Republic of Korea

2 Biological Resource Center/Korean Collection for Type Cultures (KCTC), Korea Research Institute of Bioscience and Biotechnology, Jeonbuk 56212, Republic of Korea

3 Ifremer, DYNECO, Laboratoire Phycotoxines, rue de l'lle d'Yeu, Nantes 03, F-44311 France

4 Ifremer, LITTORAL, LER BO, Station de Biologie Marine, Place de la Croix, BP40537, F-29185

Concarneau Cedex, France

${ }^{5}$ Marine Biotechnology Research Center, Korea Institute of Ocean Science \& Technology, Busan

49111, Republic of Korea

${ }^{6}$ Daegu Center, Korea Basic Science Institute (KBSI), Daegu, Republic of Korea

${ }^{7}$ Marine Ecosystem Research Center, Korea Institute of Ocean Science \& Technology, Busan 49111, Republic of Korea

${ }^{8}$ Environment and Resource Convergence Center, Advanced Institute of Convergence Technology,

Suwon 16229, Republic of Korea

${ }^{9}$ Marine Ecology Research Center, Yeosu 59697, Republic of Korea

${ }_{10}$ National Institute of Fisheries Science, Busan, 619-705, Republic of Korea

* Corresponding author : Hyeon Ho Shin, email address : shh961121@kiost.ac.kr

\begin{abstract}
:
Centrodinium punctatum is a fusiform dinoflagellate with a global marine distribution. Due to a close phylogenetic relationship of one C. punctatum strain to Alexandrium species, toxin production of this C. punctatum strain was assessed using liquid chromatography coupled to tandem mass spectrometry. The paralytic shellfish toxin (PST) profile of C. punctatum was dominated by six analogs, i.e. STX (30\%), GTX-1 $(20 \%)$ and neoSTX (24\%), followed by GTX-2 (9\%), GTX-4 (9\%) and GTX-3 (8\%); deoxy-STX was also putatively identified while no gymnodimines, spirolides or goniodomins were detected. This is the first record of C. punctatum producing saxitoxins. The estimated cellular toxicity was rather elevated, between 91 and 212 pg cell-1 (or 259 and $601 \mathrm{fmol}$ cell-1). When considering the toxicity equivalent factors, results suggest that this species can produce high cellular toxicity compared to other STX-producing dinoflagellates. Morphological details of the sulcal area and the hypotheca of Centrodinium punctatum were re-examined by scanning electron microscopy (SEM); this revealed that in the sulcal area, the left posterior sulcal plate (Ssp) is larger and longer than the left posterior sulcal plate and extended into the hypotheca. Based on the morphological observation, a revised interpretation of the sulcus and hypotheca is proposed.
\end{abstract}

Keywords : Dinoflagellate, Alexandrium, PST, STX, neoSTX, Gonyautoxin 


\section{Introduction}

The structure of saxitoxin has been clarified in 1975 and > 50 analogs have now been identified in several marine dinoflagellates and some freshwater cyanobacteria (Wiese et al., 2010), and paralytic shellfish poisoning (PSP) has been reported for more than 80 years (e.g. Sommer et al. 1937; extensively reviewed in Anderson et al., 2012; Yñiguez et al., 2020).-- Especially in the 1980s and 1990s, several PSP outbreaks in many coastal areas have caused human intoxications and death, serious economic losses in fisheries industries and negative impacts on marine ecosystems (e.g. Chang et al. 1987; Hallegraeff, 1993; Azanza and Taylor, 2001; Anderson et al. 2012). Due to such outbreaks, regular monitoring of dinoflagellates in the water column and of toxins in shellfish is typically carried out in many coastal areas of the world (e.g. EFSA, 2009; Nagai et al., 2019).

To date, $\underline{16}$ a dozen species belonging toof three genera (14 Alexandrium species, Gymnodinium catenatum and Pyrodinium bahamense) have been reported as the main toxic dinoflagellates producing STX and analogs and are hence responsible for PSP (Harada et al., 1982; Oshima 1987; Anderson et al., 1994; Taylor et al., 2003; Moestrup et al., 2009; Tomas et al., 2012; John et al., 2014; Murray et al., 2015; Lassus et al., 2016; Band-Schmidt et al., 2019; Mertens et al., 2020). Of these, Alexandrium species are most significant because they are frequently abundant and globally spread STX producers in subarctic, temperate and tropical areas (Anderson et al., 1994; Taylor et al., 2003; Hallegraeff, 2003). According to Anderson et al. (2012), among the more than 30 species in the genus Alexandrium, at least half are known to be toxic or to have otherwise harmful effects, and in particular, the Alexandrium tamarense complex (A. marense and related species), and A. minutum are currently considered to be important toxic species in many coastal areas.

The taxonomic identification of Alexandrium species is based on a unique combination of morphological characters. Such characters include the cell size and shape, the shapeform of the first apical and sixth precingular plate, the thecal ornamentation, the presence or absence of sulcal lists, the shape of the apical pore, the size and shape of the sulcal plates, the presence or absence of a ventral pore, and the connection between the pore plate and the 1' plate (Balech, 1995). More recent studies combine this with additional molecular sequence data for species identification (Lilly et al., 2005; Orr 
et al., 2011; Gu et al., 2013; Shin et al., 2014). In Li et al. (2019), we found that the genus Alexandrium is not monophyletic, due to the nesting of the fusiform dinoflagellate Centrodinium punctatum within Alexandrium species, despite morphological differences between both genera. Centrodinium species have rarely been reported, and their taxonomic and phylogenetic positions, distribution and ecophysiological characteristics are unstudied

Li et al. (2019) postulated that $C$. punctatum does not produce STXs, based on lacking sxtA gene, and thus no analysis of STXs was carried out. However, such causal relationship between stxA gene and STX production requires further investigation, as some exceptions are known (Stüken et al., 2011; Orr et al., 2013). C. punctatum displayed the closest genetic resemblance to A. affine (Li et al., 2019). According to Orr et al. (2011), A. affine is a non-STX producing species at the base of a clade containing most of the PST producing Alexandrium species. A. affine lacks the saxitoxin genes (Stüken et al., 2011). However, Nguyen-Ngoc (2004) reported that a strain of A. affine that can produce low levels of STXs This indicates that although $C$. punctatum lacks the stxA gene, it might still produce STXs, leading us to re-investigate STX production also in C. punctatum.

In this study we foeused principally onThe present study aimed to detection theef PSTs of $C$. punctatum that has been maintained under the best culture conditions as obtained in preliminary experiments-optimal culture conditions. Based on the results obtained by liquid chromatography coupled to tandem mass spectrometry (LC-MS/MS), the present studywe reports presence of STXs in a strain of $C$. punctatum and describes $C$. punctatum as a PST producer. In addition, as the molecular phylogeny and morphological relationships between Centrodinium and Alexandrium species has attracted increasing attention (e.g. Gómez and Artigas, 2019; Mertens et al., 2020), the plate configuration is reinvestigated to correct the sulcal area of $C$. punctatum.

because Gómez and Artigas (2019) suggested inaccuracies in the hypothecal tabulation of C. punctatum Formatted: Font: Italic described by Liet al., (2019), the plate configuration in the suleal area of C. punctatum is reinvestigated.

\section{Materials and methods}

\subsection{Culture maintenance}


The geographic origin of the strain (LIMS-PS-2525) of $C$. punctatum was the East China Sea $\left(31^{\circ} 59^{\prime} 53^{\prime \prime} \mathrm{N}, 127^{\circ} 41^{\prime} 59^{\prime \prime} \mathrm{E}\right)$. Cultures were established from the strain maintained in the Library of Marine Samples, Korea Institute of Ocean Science and Technology, Republic of Korea. The strain was maintained in $2 \mathrm{~L}$ culture bottles (SPL, Pocheon, Korea) containing f/2 culture medium (Marine Water Enrichment Solution, Sigma Aldrich, St. Louis, MO, USA), prepared with sterile seawater (filtered through $47 \mathrm{~mm}$ membrane filter and autoclaved). Cultures were maintained at $20_{-}^{\circ} \mathrm{C}$ and ca $100 \mu \mathrm{mol}$ photons $\mathrm{m}^{-2-2} \mathrm{~s}^{-1}-^{+}-$with cool-white illumination under a 24L:0D photo-cycle on a roller apparatus (Wheaton, Millville, NJ, USA), as a preliminary comparisonthe culture test indicated that cell growth of $C$. punctatum under a 12L:12D photo-period is lower than that under a 24L:0D photo-cycle does not without a roller apparatus (Fig. S2). The samples for toxin analysis were harvested after 30 days of incubation. Cells incubated under a 12L:12D photo-period might be sufficient for toxin analysis, but need to be tested (Fig. S1).

\subsection{Morphological study of Centrodinium punctatum}

To study the morphological features of $C$. punctatum, including the sulcus, cells were isolated from culture flasks and were photographed using an AxioCam MRc digital camera on an upright microscope (Axio Imager 2; Carl Zeiss, Jena, Germany).

For scanning electron microscopy (SEM) of the established cultures, $2 \mathrm{~mL}$ of the cultures were fixed with $2 \%$ acidic Lugol's solution (Sigma-Aldrich, St. Louis, MO, USA) for 15 min at room temperature. Subsequently, the fixed cells were passed through a $2.0 \mu \mathrm{m}$ pore size membrane filters $(22$ $\mathrm{mm}$ diameter). The filters were rinsed with deionized water and dehydrated in a graded ethanol series (10-99.9\% in eight steps) for $15 \mathrm{~min}$ at each step. The filters were then critical point dried using a critical point drying (SPI-Dry Regular Critical Point Dryer, SPI Supplies, West Chester, PA, USA) from liquid $\mathrm{CO}_{2}$. Finally, the filters were mounted on stubs, coated with platinum and examined at a voltage of $5 \mathrm{kV}$ under a JEOL JSM 7600F field emission scanning electron microscope (JEOL Ltd, Tokyo, Japan). 


\subsection{Toxin analysis}

For toxin analysis, $2 \mathrm{~L}$ of bulk cultures were filtered using a nylon net with a mesh size of $20 \mu \mathrm{m}$.

Cells were transferred into a $1.5 \mathrm{ml}$ tube and centrifuged at $3000 \times g$ at $4{ }^{\circ} \mathrm{C}$ for $10 \mathrm{~min}$. The supernatant was gently removed and the cell pellets were freeze-dried at $-70{ }^{\circ} \mathrm{C}$ (FDU-7012, Operon, Korea). Freeze-drying has been used for over a decade for the stabilization of shellfish tissues contaminated with lipophilic algal toxins (McCarron et al., 2007). C-toxins have also been shown to be stable in freeze-dried tissues of shellfish tissues (Band-Schmidt, 2005). More recently, freeze-drying has been systematically compared to wet-frozen storage and has been shown to be a better stabilization technique for saxitoxins, including C-toxins, in biological tissues (Turner et al., 2013). The same technique has also frequently been used for sample pretreatment concerning dinoflagellate cells, including saxitoxin producers (e.g. Halme et al., 2012)

Duplicateion samples-(LIMS P2 2525C1 and LIMS P2 2525 C2) containing 412,500 and 420,000 cells, respectively, were used for PSTtoxin analysis (Table 1). For the analysis of PSTs, the freeze-dried samples were extracted with acetic acid 1\% (Turner et al., 2019), in an ultrasonic bath (15 $\min , 25 \mathrm{kHz})$. After centrifugation $\left(10,000 \mathrm{~g}\right.$ at $4{ }_{-}^{\circ} \mathrm{C}$ for $\left.5 \mathrm{~min}\right)$, the supernatant was purified by Solid Phase Extraction (SPE) with an ENVI-carb cartridge (250 mg, Supelco), based on the method of Boundy et al. (2015). The analysis of PSTs was performed by HILIC-MS/MS (hydrophilic interaction liquid chromatography).

Liquid chromatography was conducted according to Turner et al. (2019), with a minor modification: the use of a Poroshell 120 HILIC-Z analytical column ( 150 x $2.1 \mathrm{~mm}, 2.7 \mu \mathrm{m}$, Agilent) coupled to a Nexera Ultra-Fast Liquid Chromatography system (Shimadzu, Tokyo, JapanFrance). The linear gradient elution program of the binary mobile phase (solvent A: water/formic acid/ammonium hydroxide (500:0.075:0.3, v/v/v); solvent B: acetonitrile/water/formic acid (900:100:0.1 v/v/v)) was as follows: 0 min, $15 \%$ A; 8.25 min, $25 \%$ A, 9 min, $50 \%$ A; $11.25 \min , 50 \%$ A, 12 min, $15 \%$ A, maintained for $7 \mathrm{~min}$. The flow rate was $0.5 \mathrm{~mL} \mathrm{~min}^{-1}$, the column temperature $30{ }^{\circ} \mathrm{C}$ while samples were kept at 
The MS/MS analysis was conducted with a hybrid triple quadrupole/linear ion-trap mass spectrometer (QTRAP 5500, ABSciex, Redwood city, CA, USA). The electrospray switched between negative and positive ionizations and the detection was performed by MRM (Multiple Reaction monitoring) with two transitions per toxin (Supplementary table S1). Samples were quantified with matrix-matched calibration curves prepared by spiking an acetic acid extract of a non-PST producing A. minutum strain before SPE clean up. Limits of detection and quantification were provided in table

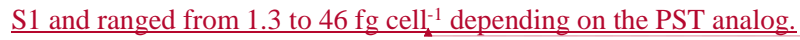

Certified calibration solutions for the PSP toxins were acquired from the National Research Council Canada (NRCC, Halifax, NS, Canada) and included C toxins (C1 and C2), gonyautoxin (GTX-1 to -6, and decarbamoyl dcGTX-2 and dcGTX-3) and saxitoxins (STX, neoSTX (NEO) and decarbamoyl dcSTX and dcNEO). In addition, analysis of spirolides (17 analogs), gymnodimines (7 analogs) and

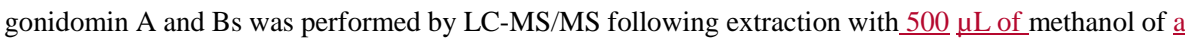
third independent replicate replicate LIMS P2 2325-C3-(80,000 cells) according to previously published protocols (Mertens et al., 2017; Krock et al., 2018; Qiu et al., 2018; Zurhelle et al., 2018; Supplementary table S2). Limits of detection and quantification for the two available standards (13desmethyl-spirolide C and GYM A obtained from NRCC, Halifax, NS, Canada) were $8.8 \mathrm{fg} \mathrm{cell}^{-1}$, as given in supplementary table S2.

\section{Results and discussion}

\subsection{Morphology of Centrodinium punctatum}

Morphological features of C. punctatum were previously documented (Li et al., 2019). The thecal surface of cell was strongly areolated, which was clearly visible with a light microscope (Fig. 1A-C), and the nucleus was elongated and located on the right-lateral side of the cell (Fig. 1C). The epitheca was prolonged in an apical horn (Fig. 1A, D), and the hypotheca also extended into an antapical horn, which was longer than the apical horn (Fig. 1A, D). The cingulum descended by about one cingulum width (Fig. 1D). The cells displayed a plate formula of Po, 3', 1a, 6", 6C, 8S, 5"', 2"'!' (Fig. 1D-I). In-Li 
et al. (2019), we described that the cells had an additional posterior intercalary plate (1p) that contacted plates $1^{\prime \prime \prime \prime}$ and $2^{\prime \prime \prime \prime}$, and that the right (Sdp) and left posterior sulcal (Ssp) plates had a similar length, based on an internal view of sulcal plates (Li et al., 2019). However, new SEM observations revealed that the left posterior sulcal plate (Ssp) extended into the hypotheca (Fig. 1G, I) and was larger and longer than the Sdp. This agrees with Gómez and Artigas (2019), who pointed out this inaccuracy in the hypothecal tabulation induced by mislabeling of the Ssp of $C$. punctatum. However, the drawing of the hypotheca provided by Gómez and Artigas (2019) is here considered inaccurate, presumably because of the lack of detailed SEM observations; in particular, Gómez and Artigas (2019) did not correctly describe the shape and location of the posterior sulcal plate $(\mathrm{Sp})$. Therefore, re doeument the sulcal plates and hypothecal plate configuration of $C$. punctatum are reinvestigated in this study $;$ Tthere are eight sulcal plates in C. punctatum, consisting of the anterior sulcal plate (Sa), the right (Sda) and left (Ssa) anterior sulcal plates, the anterior median sulcal plate (Sma), the posterior median sulcal plate (Smp), right (Ssp) and left (Sdp) posterior sulcal plates, and the posterior sulcal plate (Sp) (Fig. $2 \mathrm{~A})_{5} ;$ Tand the hypotheca is composed of five postcingular plates and two antapical plates, and the $\mathrm{Sp}$ is polygonal, larger than plates $1^{\prime \prime \prime \prime}$ and $2^{\prime \prime \prime \prime}$ and contactedwith plates $4^{\prime \prime \prime}, 5^{\prime \prime \prime}, 1^{\prime \prime \prime \prime}, 2^{\prime \prime \prime \prime}$ and Ssp (Fig. 2B)

\subsection{Toxin profile and toxicity of Centrodinium punctatum}

Several PST analogs were detected in the $C$. punctatum strain (Table 1 and Fig. 3 ). The total PST concentrations for the duplicatetwo individual samples (LIMS-PS-2525-C1 and C2) were 91 and 212 pg cell- ${ }^{-1}$ (or 259 and $601 \mathrm{fmol} \mathrm{cell}^{-1}$ ), corresponding respectively to 99 and 230 pg STXeq cell ${ }^{-1}$ when toxicity equivalent factors based on Botana et al. (2017) were considered. It is not clear why the two replicates, established from separate cultures maintained under the same conditions, showed such a large difference in PST concentrations. Despite of the difference in total PSTs, the proportions of each analog for the two samples were in excellent agreement, showing that STX, GTX-1 and neoSTX were the principle analogs (>70\% of the profile) followed by GTX-4, -2 and -3 (Fig. 3 and Fig. S3). In addition, deoxydecarbamoyl STX (do-STX) was putatively detected at trace level; as no standard was available for confirmation, identification was based on both MRM transitions and the relative retention 
time compared to STX (Boundy et al., 2015). Neither C-toxins nor decarbamoyl analogs (except a trace of doSTX) were detected in the strain of $C$. punctatum. Similarly, no spirolide, gymnodimine and gonidomin could be detected.

Despite of morphological differences between C. punctatum and Alexandrium species, C. punctatum is phylogenetically closely related to Alexandrium species, and in particular to A. affine (see Figs 9 and 10 in Li et al., 2019). Some studies found that strains of $A$. affine do not produce PSTs (BandSchmidt et al., 2003; Wang et al., 2006; Orr et al., 2011), whereas Nguyen-Ngoc (2004) documented a strain of A. affine that produces six PSTs consisting of neoSTX, STX, GTX-1, GTX-2, GTX-3 and GTX-4. Toxin profiles of A. affine in Nguyen-Ngoc (2004) are similar -to the profile found in this study of $C$. punctatum. This indicates that the close phylogenetic relationship between $A$. affine and $C$. punctatum could potentially also be reflected in a similarity between both toxin profiles. However, doubts about detection limits and analogue identity due to the fluorescence detection method used by Nguyen-Ngoc (2004) suggest that $A$. affine's toxin profile should be re-investigated.

Although PST profiles and concentrations are affected by variable factors, the PST profiles of Alexandrium species such as A. acatenella, A. affine, A. andersonii, A. australiense, A. catenella, A. cohorticula, A. fundyense, A. leei, A. minutum, A. ostenfeldii, A. pacificum, A. peruvianum, A. tamiyavanichii, and A. taylorii usually include STXs, GTXs, and C-toxins (Anderson et al., 1994; Yoshida et al., 2001; Hansen et al., 2003; Orr et al., 2011; John et al., 2014; Murray et al., 2015; Lassus et al., 2016; but see Tillmann et al., 2020 for A. taylorii), and some possess high concentrations of STX and neoSTX (Anderson et al., 1994; John et al., 2014). Importantly, in several toxin profiles, the Ctoxins are consistently detected in many toxic strains of Alexandrium species (e.g., Yoshida et al., 2001; Lim et al., 2006; Wang et al., 2006; Orr et al., 2011; Laabir et al., 2013; John et al., 2014; Band-Schmidt et al., 2019), however this was not the case for C. punctatum. Interestingly, Pacific strains of A. minutum do not appear to produce C-toxins, while strains from Denmark and France do produce C-toxins (Lassus et al., 2016; Lewis et al., 2018). Such differences clearly indicate the need to evaluate more strains of C. punctatum from different geographical regions for their toxin production. Additionally, according to the results on toxin contents between life stages of A. fundyense by Persson et al. (2012), gonyautoxins 
such as GTX-1 and -2 are present or absent in different life stages, whereas the presence of C-toxins such as $\mathrm{C} 2$ is conserved. Such studies indicate that the PST-profile can be life stage dependent; so far no other life stage is known for $C$. punctatum, and thus this variability cannot be assessed here. Ameng other PST producing dinoflagellates, $G$. catenam can also produce the $C$ toxins, however this species has been reported to produce benzoyl analogs (GC toxins) that have not been detected in toxic Alexandrium species and not screened for in the present study (Band-Schmidt et al., 2019), similar to A toxins, another PST variant recently also discovered in cyanobacteria (D'Agostino et al., 2019).

The toxin profile of the strain of $C$. punctatum iswas highly unusual, with high proportions of STX and neoSTX (that accounted for ca. $48 \%$ of the total toxins), which have not commonly been reported in strains of toxic Alexandrium species. The gonyautoxins in this strain of C. punctatum accounted for the rest of the total toxin concentrations. According to Botana et al. (2017), in the mouse bioassays, STX and neoSTX are the most toxic and followed by gonyautoxins, indicating that $C$. punctatum can produce a high level of toxicity compared to Alexandrium species. In addition, the maximal cellular PST quota (230 pg STXeq cell ${ }^{-1}$ or $601 \mathrm{fmol} \mathrm{cell}^{-1}$ ) of $C$. punctatum is rather high. Indeed, from many strains of worldwide distributed PST producing dinoflagellates such as For Alexandrium species, $-G$. eatenam and $P$. bahamense, the highest reported cellular toxicity was $450 \mathrm{fmol} \mathrm{cell}^{-1}$ (Laabir et al., 2013 and references therein). HoweverIn fact, it is quite difficult to compare the cellular toxicity between $C$. punctatum and suchether related species since cellular toxicity of Alexandrium speciesPST producing dinoflagellates varies considerably interwithin and intraspecificallybetween species, and between geographically distinct populations (e.g., Anderson et al., 1990, 2012; Cembella, 1998; Orlova et al., 2007; Persson et al., 2012; Van de Waal et al., 2013).

In this study, the strain of $C$. punctatum was established from a single celleells isolated in the East China Sea (Li et al., 2019). The East China Sea is connected with the East Sea (Sea of Japan) of Korea (Sea of Japan) through the Korea Strait, and opens to the north into the Yellow Sea. Along the continental slope of the East China Sea, the Taiwan Warm Current and the Tsushima Current that branch from the Kuroshio Current, enter into the Korean and Japanese coastal areas (Lie and Cho, 1994; Hu and Yang, 2001). These currents have been suggested to transport harmful species such as 
Margalefidinium polykrikoides and Prorocentrum obtusidens into Korean and Japanese coastal areas (Lee, 2006; Shin et al., 2019), a mechanism which may also apply to intrusions of C. punctatum. Even though blooms or harmful effects caused by $C$. punctatum have not yet been recorded in Korean and Japanese coastal areas, $C$. punctatum may have been overlooked and monitoring of this species now appears necessary to protect both the public health and the shellfish industry. In addition, further research is needed to clarify changes in toxicity of $C$. punctatum with differences in environmental factors such as temperature, salinity and nutrient or bacterial interactions and to clarify the relationship between Centrodinium and Alexandrium species. Furthermore, since $C$. punctatum and related species are widely distributed, the toxicity of other strains should be investigated in future studies as well.

3

\section{Acknowledgements}

This work was supported by grants from the Marine Biotechnology Program of the KIMST funded by the Ministry of Oceans and Fisheries (No. 20170431), NIFS (R2020041), KIOST (PE99821) projects and KRIBB research initiative program. The authors acknowledge the Interreg / Atlantic Area for funding the ALERTOX-NET project (grant number EAPA_317/2016) and the European H2020 program for funding the EMERTOX project (grant number 778069). We also would like to thank Shauna Murray and Elisabeth Nézan for constructive discussions. The comments of two anonymous reviewers and the editor have helped to substantially improve the paper. 


\section{References}

301
Anderson, D.M., Kulis, D.M., Sullivan, J.J., Hall, S., Lee, C., 1990. Dynamics and physiology of saxitoxin production by the dinoflagellate Alexandrium spp. Mar. Biol. 104, 511-524.

Anderson, D.M., Kulis, D.M., Doucette, G.J., Gallagher, J.C., Balech, E., 1994. Biogeography of toxic dinoflagellates in the genus Alexandrium from the northeastern United States and Canada. Mar. Biol. $120,467-478$.

Anderson, D.M., Alpermann, T.J., Cembella, A.D., Collos, Y., Masseret, E., Montresor, M., 2012. The globally distributed genus Alexandrium: Multifaceted roles in marine ecosystems and impacts on human health. Harmful Algae 14, 10-35.

Azanza, R.V., Taylor, F.J., 2001. Are Pyrodinium blooms in the Southeast Asian region recurring and spreading? A review at he end of the millennium. Ambio 39, 356-364.

Balech, E., 1995. The genus Alexandrium Halim (Dinoflagellata). Sherkin Island Marine Station, Sherkin Island Co., Cork, Ireland.

Band-Schmidt, C.J., Lilly, E.L., Anderson, D.M., 2003. Identification of Alexandrium affine and A. margalefii (Dinophyceae) using DNA sequencing and LSU rDNA-based RFLP-PCR assays. Phycologia 42, 261-268.

Band-Schmidt, C.J. 2005. Paralytic shellfish toxin profile in strains of the dinoflagellate Gymnodinium catenatum Graham and the scallop Argopecten ventricosus G.B. Sowerby II from Bahía Concepción, Gulf of California, Mexico. Harmful Algae 4, 21-31.

Band-Schmidt, C.J, Durán-Riveroll, L.M., Bustillos-Guzmán, J.J., Leyva-Valencia, I., López-Cortés, D.J., Núñez-Vázquez, E.J., Hernández-Sandoval, F.E., Ramirez-Rodriguez, D.V., 2019. Paralytic toxin producing dinoflagellates in Latin America: Ecology and physiology. Front. Mar. Sci. 6, 42. doi: 10.3389/fmars.2019.00042 
Botana, L.M., Hess, P., Munday, R., Nathalie, A., DeGrasse, S.L., Feeley, M., Suzuki, T., van den Berg, M., Fattori, V., Garrido Gamarro, E., Tritscher, A., Nakagawa, R., Karunasagar, I., 2017. Derivation of toxicity equivalency factors for marine biotoxins associated with Bivalve Molluscs. Trends Food Sci. Techn. 59, 15-24. doi:https://doi.org/10.1016/j.tifs.2016.09.015

Boundy, M.J., Selwood, A.I., Harwood, D.T., McNabb, P.S., Turner, A.D., 2015. Development of a sensitive and selective liquid chromatography-mass spectrometry method for high throughput analysis of paralytic shellfish toxins using graphitised carbon solid phase extraction. J. Chromatogr. A 1387, 112. doi:10.1016/j.chroma.2015.01.086

Cembella, A.D., 1998. Ecophysiology and metabolism of paralytic shellfish toxins in marine microalgae. In: Anderson, D.M., Cembella, A.D., Hallegraeff, G.M. (Eds.), Physiological Ecology of Harmful Algal Blooms. Springer Verlag, Heidelberg, pp. 381-403

Chang, D.S., Shin, I.S., Pyeun, J.H., Park, Y.H., 1987. A study on paralytic shellfish poison of sea mussel Mytilus edulis. Bull. Kor. Soc. Fish. Tech. 20, 293-299.

EFSA, 2009. Scientific Opinion of the Panel on Contaminants in the Food Chain on a request from the European Commission on Marine Biotoxins in Shellfish - Saxitoxin Group. The EFSA Journal $1019,1-76$.

Gómez, F., Artigas, L.F., 2019. Redefinition of the dinoflagellate genus Alexandrium based on Centrodinium: Reinstatement of Gessnerium and Protogonyaulax, and Episemicolon gen. nov. (Gonyaulacales, Dinophyceae). Hindawi J. Mar. Biol., 1284104.

Gu, H., Zeng, N., Liu, T., Yang, W., Müller, A., Krock, B., 2013. Morphology, toxicity, and phylogeny of Alexandrium (Dinophyceae) species along the coast of China. Harmful Algae 27, 68-81.

Hallegraeff, G.M., 1993. A review of harmful algal blooms and their apparent globral increase. Phycologia 32, 79-99.

Hallegraeff, G.M., 2003. Harmful Algal Blooms: a global overview. In: Hallegraeff, G.M., Anderson, D.M., Cembella, A.D. (Eds.), Manual on Harmful Marine Microalgae. Monographs on oceanographic methodology 11. UNESCO Publishing, Paris, pp. 25-49. 
Halme, M., Rapinoja, M.-L., Karjalainen, M., Vanninen, P., 2012. Verification and quantification of saxitoxin from algal samples using fast and validated hydrophilic interaction liquid chromatographytandem mass spectrometry method. Journal of chromatography. B, Analytical technologies in the biomedical and life sciences. 880, 50-57.

Hansen, G., Daugbjerg, N., Franco, J.M., 2003. Morphology, toxin composition and LSU rDNA phylogeny of Alexandrium minutum (Dinophyceae) from Denmark, with some morphological observations on other European strains. Harmful Algae 2, 317-335.

Harada, T., Oshima, Y., Kamiya, H., Yasumoto, T., 1982. Confirmation of paralytic shellfish toxins in the dinoflagellate Pyrodinium bahamense var. compressa and bivalves in Palau. Bull. Japan Soc. Sci. Fish $48,821-825$

Hu, D.X., Yang, Z.S., 2001. The key process of marine fluxes in East China Sea. Ocean Press, Beijing. John, U., Litaker, R.W., Montresor, M., Murray, S., Brosnahan, M.L., Anderson, D.M., 2014. Formal revision of the Alexandrium tamarense species complex (Dinophyceae) taxonomy: The introduction of five species with emphasis on molecular-based (rDNA) classification. Protist 165, 779-804.

Laabir, M., Collos, Y., Masseret, E., Grzebyk, D., Abadie, E., Savar, V., Sibat, M., Amzil, Z., 2013. Influence of environmental factors on the paralytic shellfish toxin content and profile of Alexandrium catenella (Dinophyceae) isolated from the Mediterranean Sea. Mar. Drugs 11, 1583-1601.

Lassus P., Chomérat, N., Hess, P., Nézan, E., 2016. Toxic and Harmful Microalgae of the World Ocean / Micro-algues toxiques et nuisibles de l'océan mondial. Denmark, International Society for the Study of Harmful Algae / Intergovernmental Oceanographic Commission of UNESCO. IOC Manuals and Guides, 68 [Bilingual English/French].

Lewis, A.M., Coates, L.N.Coates, Turner, A.D.Turner, Percy,_L. Percy, and Lewis, J.Lewis. 2018. A 
review of the global distribution of Alexandrium minutum (Dinophyceae) and comments on ecology and associated paralytic shellfish toxin profiles, with a focus on Northern Europe. J. Phycol. $54_{2} \div 581$ 598.

Lee, Y.S., 2006. Factors affecting outbreaks of high-density Cochlodinium polykrikoides red tides in the coastal seawaters around Yeosu and Tongyeong, Korea. Mar. Pollut. Bull. 52,1249-1259.

Lilly, E.L., Halanych, K.M., Anderson, D.M., 2005. Phylogeny, biogeography, and species boundaries within the Alexandrium minutum group. Harmful Algae 4, 1004-1020.

Li, Z., Mertens, K.N., Nézan, E., Chomérat, N., Bilien, G., Iwataki, M., Shin, H.H., 2019. Discovery of a new clade nested within the genus Alexandrium (Dinophyceae): Morpho-molecular characterization of Centrodinium punctatum (Cleve) F.J.R. Taylor. Protist 170(2), 168-186.

Lie, H.J., Cho, C.H., 1994. On the origin of the Tsushima Warm Current. J. Geophys. Res. 99, 2508125091

Lim, P.T., Leaw, C.P., Usup, G., Kobiyama, A., Koike, K., Ogata, T., 2006. Effects of light and temperature on growth, nitrate uptake, and toxin production of two tropical dinoflagellates: Alexandrium tamiyavanichii and Alexandrium minutum (Dinophyceae). J. Phycol. 42, 786-799.

McCarron, P., Emteborg, H., Hess, P., 2007. Freeze-drying for the stabilisation of shellfish toxins in mussel tissue (Mytilus edulis) reference materials. Anal. Bioanal. Chem. 387, 2475-2486.

Mertens, K.N., Adachi, M., Anderson, D.M., Band-Schmidt, C.J., Bravo, I., Brosnahan, M.L., Bolch, C.J.S., Calado, A.J., Carbonell-Moore, M.C., Chomérat, N., Elbrächter, M., Figuera, R.I., Fraga, S., Gárate-Lizárraga, I., Gracés, E., Gu, H., Hallegraeff, G., Hess, P., Hoppenarath, M., Horiguchi, T., Iwataki, M., John, U., Kremp, A., Larsen, J., Leaw, C.P., Li, Z., Lim, P.T., Litaker, W., MacKenzie, L., Masseret, E., Matsuoka, K., Moestrup, Ø, Montresor, M., Nagai, S., Nézan, E., Nishimura, T., Okolodkov, Y.B., Orlova, T.Y., Reñe, A., Sampedro, N., Satta, C.T., Shin, H.H., Siano, R., Smith, K.F., Steidinger, K., Takano, Y., Tillmann, U., Wolny, J., Yamaguchi, A., Murray S., 2020. Morphological and phylogenetic data do not support the split of Alexandrium into for genera. Harmful Algae 98,

\begin{tabular}{l} 
Formatted: Font: Times New Roman \\
Formatted: Font: Times New Roman \\
\hline Formatted: Font: Times New Roman \\
\hline Formatted: Font: Times New Roman \\
Formatted: Font: Times New Roman \\
Formatted: Font: Times New Roman \\
Formatted: Font: Times New Roman \\
Formatted: Font: Times New Roman \\
Formatted: Font: Italic \\
\hline
\end{tabular}


101902.

Moestrup, Ø., Akselmann-Cardella, R., Churro, C., Fraga, S., Hoppenrath, M., Iwataki, M., Larsen, J., Lundholm, N., Zingone, A. (Eds.), 2009 onwards. IOC-UNESCO Taxonomic Reference List of Harmful Micro Algae. Accessed at http://www.marinespecies.org/hab on 2020-02-20. https://doi:10.14284/362

Murray, S.A., Diwan, R., Orr, R.J., Kohli, G.S., John, U., 2015. Gene duplication, loss and selection in the evolution of saxitoxin biosynthesis in alveolates. Mol. Phylogenet. Evol. 92, 165-180.

Nagai, S., Chen, H., Kawakami, Y., Yamamoto, K., Sildever, S., Kanno, N., Oikawa, H., Yasuike, M., Nakamura, Y., Hongo, Y., Fujiwara, A., Kobayashi, T., Gojobori, T., 2019. Monitoring of the toxic dinoflagellate Alexandrium catenella in Osaka Bay, Japan using a massively parallel sequencing (MPS)-based technique. Harmful Algae 89, 101660.

Nguyen-Ngoc, L., 2004. An autecological study of the potentially toxic dinoflagellate Alexandrium affine isolated from Vietnamese waters. Harmful Algae 3, 117-129.

Orr, R.J.S., Stüken, A., Rundberget, T., Eikrem, W., Jakobsen, K.S., 2011. Improved phylogenetic resolution of toxic and nontoxic Alexandrium strains using a concatenated rDNA approach. Harmful Algae 10, 676-688.

Orr, R.J.S., Stüken, A., Murray, S., Jakobsen, K.S., 2013. Evolutionary acquisition and loss of saxitoxin biosynthesis in dinoflagellates: lessons from the second "core" gene-stxG. Appl. Environ. Microbiol. $79,2128-2136$

Orlova, T.Y., Selina, M.S., Lilly, E.L., Kulis, D.M., Anderson, D.M., 2007. Morphogenetic and toxin composition variability of Alexandrium tamarense (Dinophyceae) from the east coast of Russia. Phycologia 46, 534-548.

Oshima, Y., Hasegawa, M., Yasumoto, T., Hallegraeff, G., Blackburn, S., 1987. Dinoflagellate Gymnodinium catenatum as the source of paralytic shellfish toxins in Tasmanian shellfish. Toxicon 25, 1105-1111.

Persson, A., Smith, B.C., Alix, J.H., Senft-Batoh, C., Wikfors, G.H., 2012. Toxin content differs 
between life stages of Alexandrium fundyense (Dinophyceae). Harmful Algae 19, 101-107.

Shin, H.H., Baek, S.H., Li, Z., Han, M.S., Oh, S.J., Youn, S.H., Kim, Y.S., Kim, D., Lim, W.A., 2014.

Resting cysts, and effects of temperature and salinity on the growth of vegetative cells of the potentially harmful species Alexandrium insuetum Balech (Dinophyceae). Harmful Algae 39, 175-184.

Shin, H.H., Li, Z., Seo, M.H., Soh, M.Y., Lim, W.A., Park, J.W., 2019. Harmful dinoflagellate Prorocentrum donghaiense $\mathrm{Lu}$ is widely distributed along the East China Sea and Korean coastal area. Ocean Sci. J. 54, 685-691.

Sommer, H., Whedon, W.F., Kofoid, C.A., Stohler, R., 1937. Relation of paralytic shellfish poison to certain plankton organisms of the genus Gonyaulax. Arch. Pathol. 24, 537-559.

Stüken, A., Orr, R.J.S., Kellman, R., Murray, S.A., Neilan, B.A., Jakobsen, K.S., 2011. Discovery of nuclear-encoded genes for the neurotoxin saxitoxin in dinoflagellates. PLoS ONE 6-(5), 20096. https://doi.org/10.1371/journal.pone.0020096

Taylor, F.J.R., Fukuyo, Y., Larsen, J., 2003. Taxonomy of Harmful Dinoflagellates. In: Hallegraeff, G.M., Anderson, D.M., Cembella, A.D. (Eds.), Manual on Harmful Marine Microalgae. Monographs on oceanographic methodology 11. UNESCO Publishing, Paris, pp. 389-432.

Tillmann, U., Krock, B., Wietkamp, S., Beran, A., 2020. A Mediterranean Alexandrium taylorii (Dinophyceae) Strain Produces Goniodomin A and Lytic Compounds but Not Paralytic Shellfish Toxins. Toxins 12, 564. https://doi:10.3390/toxins12090564

Turner, A., Lewis, A., Hatfield, R., Higman, W., Burrell, S., 2013. A feasibility study into the production of a freeze-dried oyster reference material for paralytic shellfish poisoning toxins. Anal. Bioanal. Chem. 405, 8621-8632.

Turner, A.D., Dhanji-Rapkova, M., Fong, S.Y.T., Hungerford, J., McNabb, P.S., Boundy, M.J., Harwood, D.T., 2019. Ultrahigh-Performance Hydrophilic Interaction Liquid Chromatography with Tandem Mass Spectrometry Method for the Determination of Paralytic Shellfish Toxins and Tetrodotoxin in Mussels, Oysters, Clams, Cockles, and Scallops: Collaborative Study. J AOAC Int. https://doi:10.5740/jaoacint.19-0240 
Van de Waal, D.B., Tillmann, U., Zhu, M., Koch, B., Rost, B., John, U., 2013. Nutrient pulse induces dynamic changes in cellular $\mathrm{C}: \mathrm{N}: \mathrm{P}$, amino acids, and paralytic shellfish poisoning toxins in Alexandrium tamarense. Mar. Ecol. Prog. Ser. 493, 57-69.

Wang, D.Z., Zhang, S.G., Gu, H.F., Chan, L.L., Hong, H.S., 2006. Paralytic shellfish toxin profiles, and toxin variability of the genus Alexandrium (Dinophyceae) isolated from the Southeast China Sea. Toxicon 48, 138-151.

Wiese, M., D’Agostino, P.M., Mihali, T.K., Moffitt, M.C., Neilan, B.A., 2010. Neurotoxic alkaloids: Saxitoxin and its analogs. Mar. Drugs. 8, 2185-2211.

Yñiguez, A.T., Lim, P.T., Leaw, C.P., Jipanin, S.J., Iwataki, M., Benico, G., Azanza, R.V., 2020. Over 30 years of HABs in the Philippines and Malaysia: What have we learned? Harmful Algae, 101776. https://doi.org/10.1016/j.hal.2020.101776

Yoshida, T., Sako, Y., Uchida, A., 2001. Geographic differences in paralytic shellfish poisoining toxin profiles among Japanese populations of Alexandrium tamarense and A. catenella (Dinophyceae). Phycol. Res. 49, 13-21. 


\section{Figure legends}

Fig. 1. Light micrographs and scanning electron micrographs of Centrodinium punctatum. (A) Ventral view showing the sulcus and cingulum. (B) Dorsal view showing the cingulum. (C) Mid focus on right lateral view showing the nucleus (n). (D) Ventral view showing the left posterior sulcal plate (Ssp). (E) Dorsal-left lateral view. (F) Right lateral view. (G-H) Details of the sulcal area. (I) Antapical view showing Ssp and the posterior sulcal plate (Sp). Scale bars: $\mathrm{A}-\mathrm{F}=10 \mu \mathrm{m} ; \mathrm{G}-\mathrm{I}=3 \mu \mathrm{m}$.

Fig. 2. Diagrammatic line drawings of the sulcal area (A) and the hypotheca (B) of Centrodinium punctatum, based on scanning electron microscope observation.

Fig. 3. PST profiles (average molar concentration) of Centrodinium punctatum strain LIMSPS-2525. 

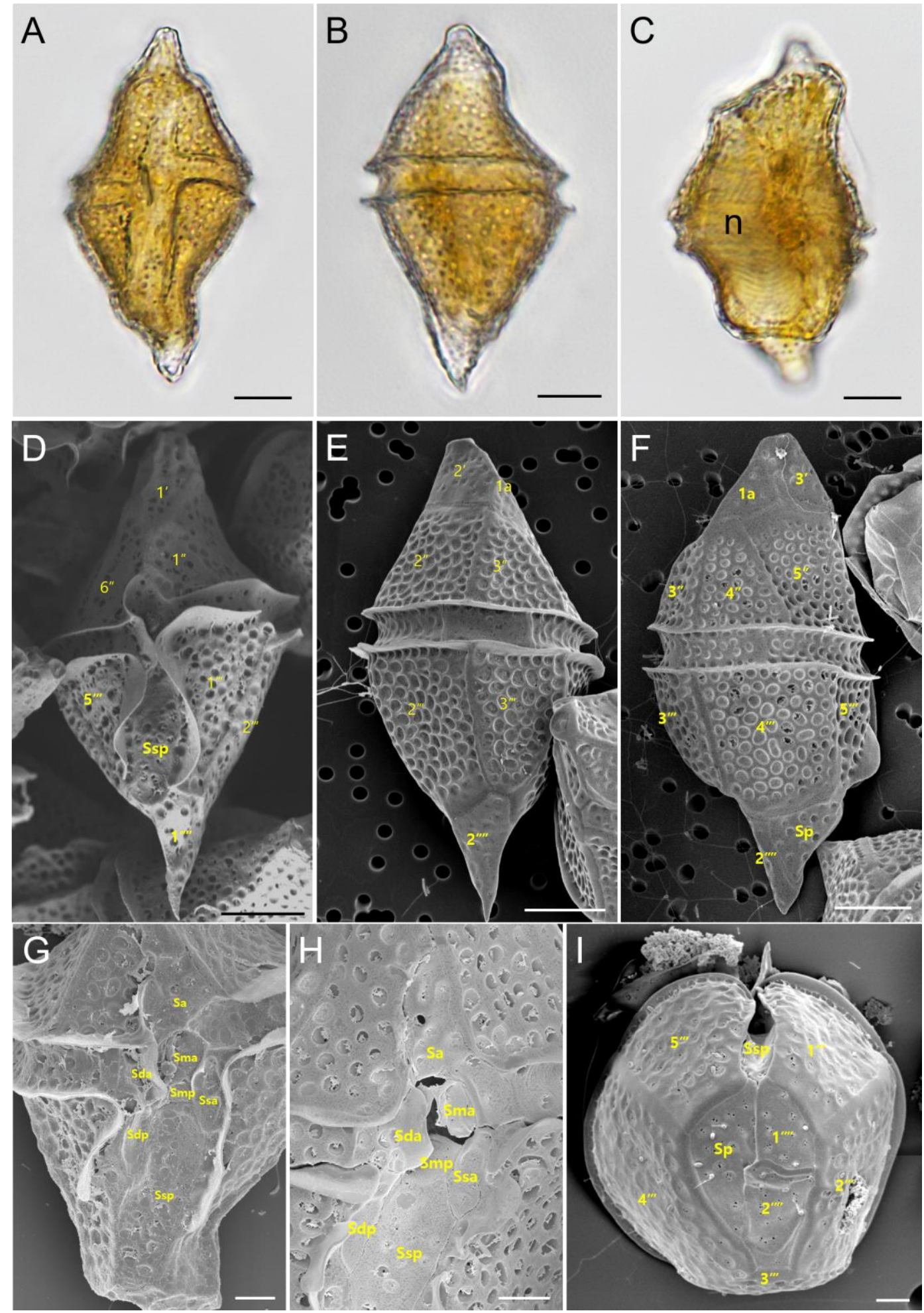

Fig. 1. 

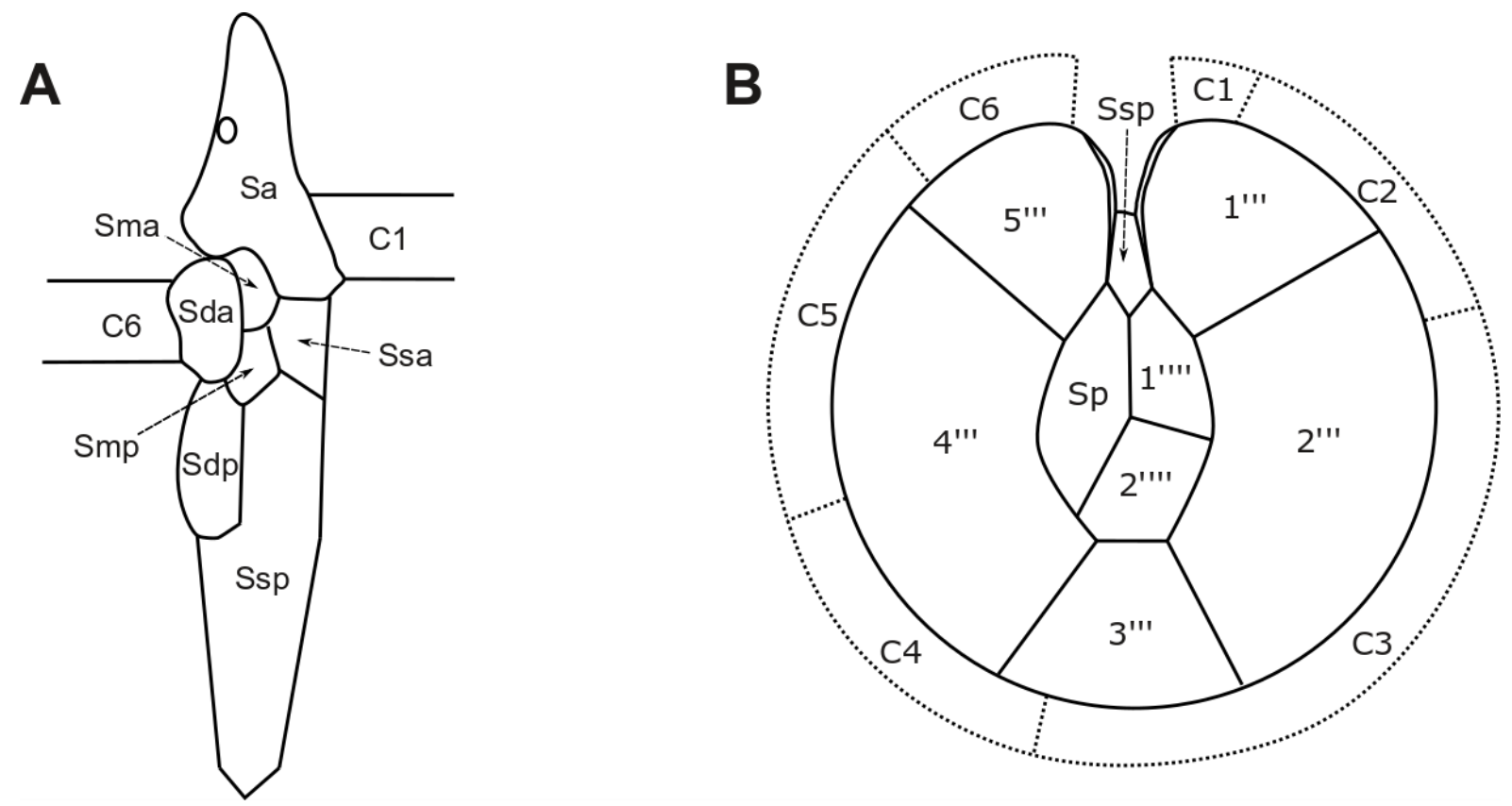

Fig. 2. 


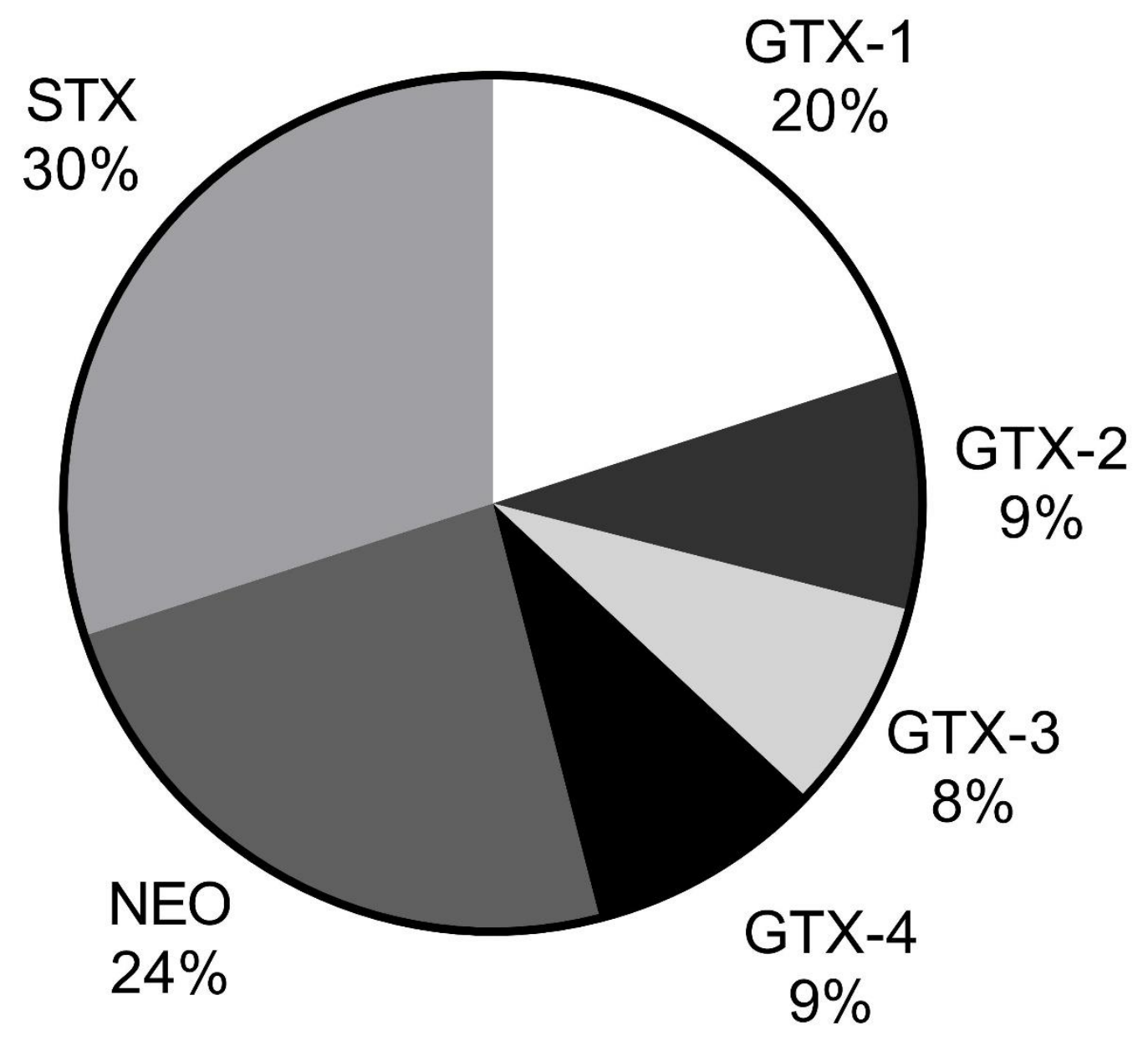

Fig. 3. 
Table 1. Toxin content (pg cell ${ }^{-1}$ ) and toxicity (pg STX-eq. cell ${ }^{-1}$, obtained by weighting by the Toxicity Equivalent Factors, TEFs, defined by Botana et al. 2017) of Centrodinium punctatum.

\begin{tabular}{lccccccc}
\hline & GTX-1 & GTX-2 & GTX-3 & GTX-4 & NEO & STX & Total $\left(\right.$ pg cell $\left.^{-1}\right)$ \\
\hline LIMS-PS-2525-C1 & 21 & 8,7 & 7,2 & 9,7 & 20 & 24 & 91 \\
LIMS-PS-2525-C2 & 50 & 21 & 18 & 23 & 45 & 53 & 212 \\
\hline & GTX-1 & GTX-2 & GTX-3 & GTX-4 & NEO & STX & Total (pg STX-eq. cell $\left.{ }^{-1}\right)$ \\
\hline LIMS-PS-2525-C1 & 21 & 3,5 & 4,3 & 6,8 & 39 & 24 & 99 \\
LIMS-PS-2525-C2 & 50 & 8,5 & 11 & 16 & 91 & 53 & 230 \\
\hline
\end{tabular}


Click here to access/download Supplementary Material Supplementary Figures_HA_202009.docx 
Click here to access/download Supplementary Material Supplementary Tables_HA_202009.docx 